\title{
The Impact of Nonrenewable Resource Abundance on Factor Shares
}

\author{
Ali Motavasseli ${ }^{1}$ \\ Najmeh Khani-Saryazdi ${ }^{2}$
}

a.motavasseli@imps.ac.ir

\begin{abstract}
The share of factors of production in the GDP of a country represents an overall picture of its aggregate production technology. The share of reproducible factors (i.e., physical capital and human capital), and the share of non-reproducible factors (i.e., natural capital and unskilled labor) from total production varies considerably across different countries. In this paper, the impact of nonrenewable resource abundance or dependence on various factor shares is studied. Cross-sectional data of countries using OLS and 2SLS estimates are investigated. The results show that the share of natural capital in GDP is higher in the countries that are more dependent on nonrenewable resources or enjoy resource abundance. Moreover, human capital share and unskilled labor share are both lower in countries with higher degrees of resource dependence. Further research is needed to shed light on how resource abundance or dependence affects factor shares of economies.
\end{abstract}

Keywords: Resource Resource Curse, Reproducible Factors, Nonreproducible Factors, Resource Abundance, Resource Dependence.

JEL Classification: E25, O13, O11.

\footnotetext{
1. Assistant Professor, Department of Economics, Institute for Management and Planning Studies, Tehran, Iran (Corresponding Author).

2. M.A. Student of Economics, Institute for Management and Planning Studies, Tehran, Iran.
} 


\section{تاثير وفور منابع تجديدنايذير بر سمهم عوامل توليد}

a.motavasseli@imps.ac.ir । نوع مقاله: بزوهشى

$$
\begin{aligned}
& \text { على متوسلى } \\
& \text { استاديار كروه اقتصاد، موسسه عالى آموزش و يزوهش مديريت } \\
& \text { وبرنامهريزى (نويسنده مسئول). } \\
& \text { نجمه خانى سريزدى (نوين } \\
& \text { دانشجوى كارشناسى ارشد اقتصاد، موسسه عالى آموزش و و } \\
& \text { يزوهش مديريت و برنامهريزى. }
\end{aligned}
$$

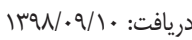

جكيده: سهم عوامل توليد از توليد ناخالص داخلى تصويرى از فناورى اقتصاد را در سطح

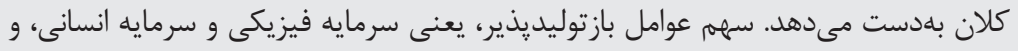

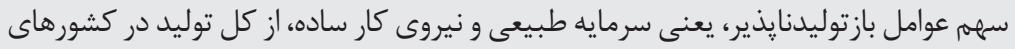

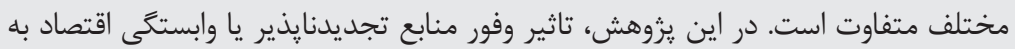

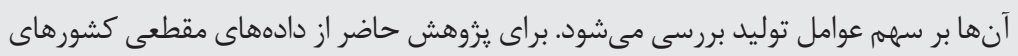

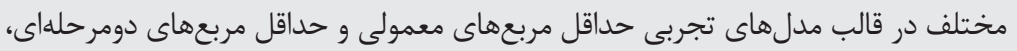

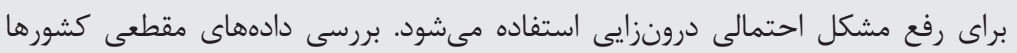

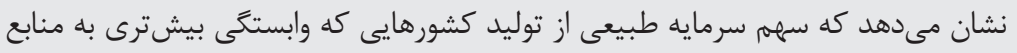

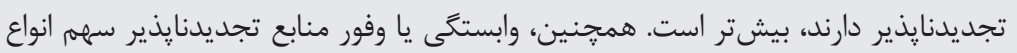

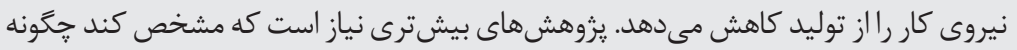

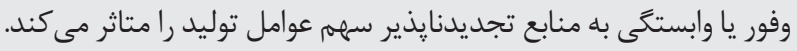

كليدوازهها: شومى منابع، عوامل بازتوليديذير، عوامل بازتوليدنايذير، وفور منابع، وابستخى به منابع.

طبقهبندى O11, O13, E25 :JEL. 
سهمم عوامل توليد در يك اقتصاد نشانكر نسبت بكارگيرى آنها در فرايند توليد است. براى مثال،

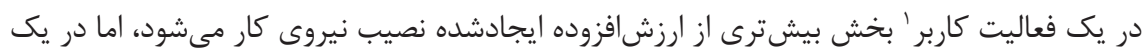

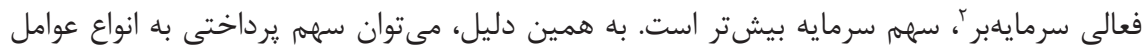

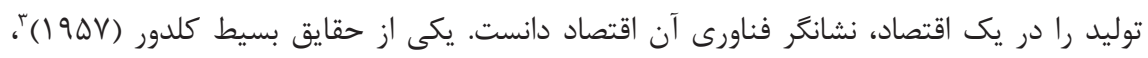

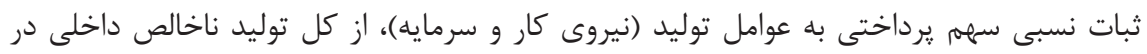

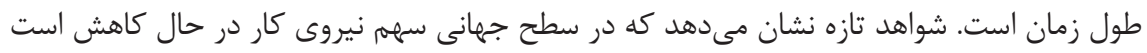

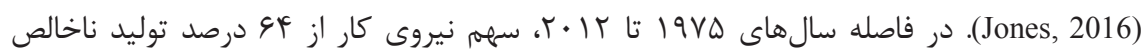

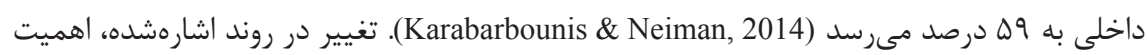
بررسى عوامل موثر را بر سهمم عوامل توليد، يا فناورى توليد، بيشتر مى كند. استور

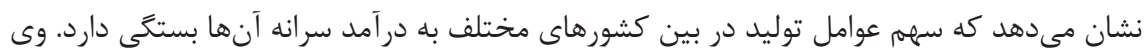

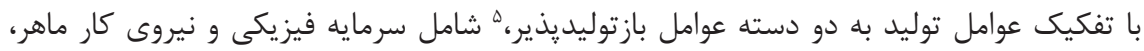

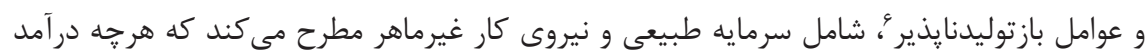

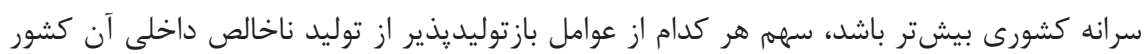

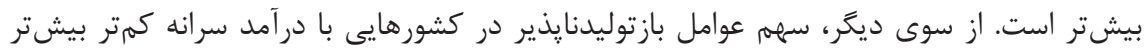

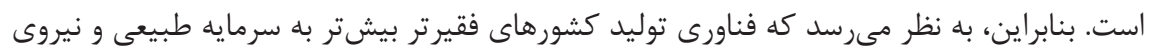
كار ساده وابسته است. در مقابل، فناورى توليد در كشورهاى ثروتمندتر بيشتر بـ به نيروى كار ماهر و و

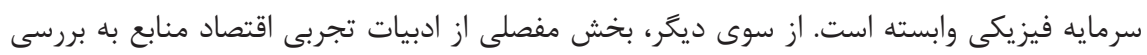

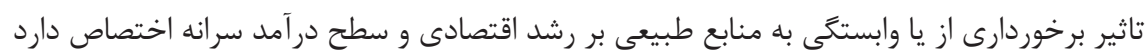
Sachs \& Warner, 1995; Brunnschweiler \& Bulte, 2008; Alexeev \& Conrad, 2009; Van der) Ploeg, 2011 (ين بخش از ادبيات اقتصادى به شومى منابع ₹مشهور است. با كنار هم قرار دادن

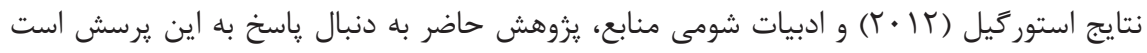

1. Labor-Intensive

2. Capital-Intensive

3. Kaldor's Stylized Facts

4. Sturgill

5. Reproducible Factors

6. Non-Reproducible Factors

7. The Resource Curse 
كه آيا سازوكار موجود در اقتصادهاى فقير، كه به كاهش سهم عوامل بازتوليديذير (يعنى نيروى كار

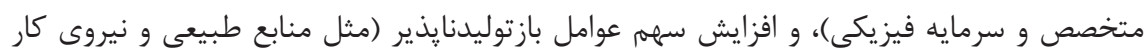

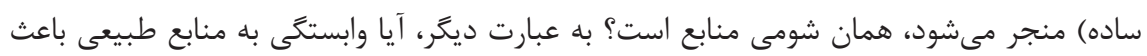
كاهش سطح در آمد سرانه كشورها و همزمان افزايش سمهم عوامل توليدى مثل منابع منابع طبيعى و نيروى

يروهش حاضر، تا جايى كه نويسندًان اطلاع دارند، نخستين يزوهشى است كه ارتباط بين

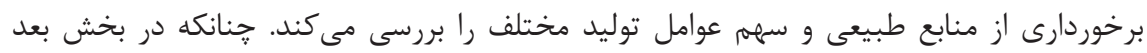

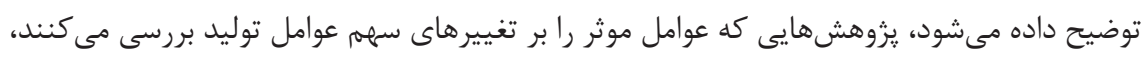

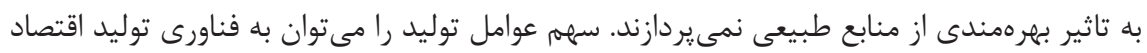

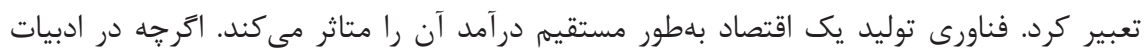

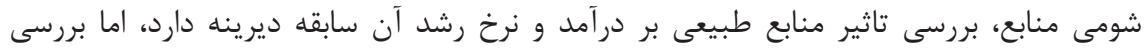
تاثير منابع طبيعى بر فناورى توليد اقتصاد تاكنون مغفول مانده است. با استفاده از محاسبه دهاى

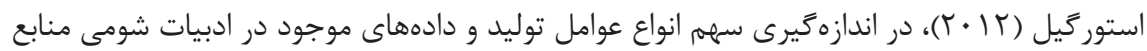

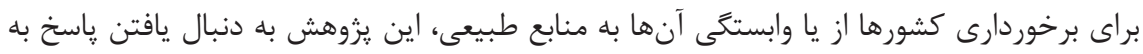
يرسش هاى مطرحشده است.

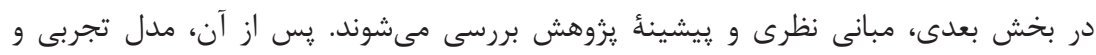

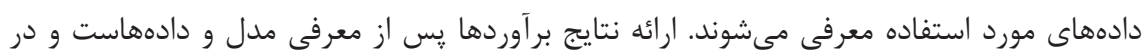
انتها نتيجه گيرى انجام مى كيرد.

\section{مبانى نظرى ثزوهش} در اقتصاد كلان استفاده از تابع توليد كاب-داكلاس' با عوامل توليد نيروى كار و سرمايه مرسوم است.

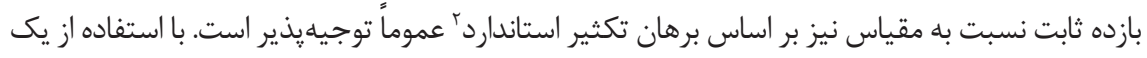

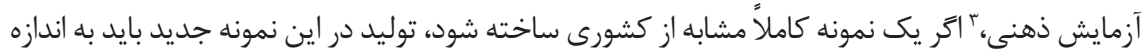
كشور اصلى باشد. بنابراين، دوبرابر كردن عوامل توليد به دوبرابر شدن توليد منجر مىشود و اين يعنى بازده

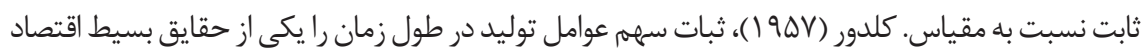

1. Cobb-Douglas

2. Standard Replication Argument

3. Thought Experiment 
كلان مى داند. يس از آن، يزوهشهاى مختلفى در مورد تغييرهاى سهم عوامل توليد در طول زمان و بين كشورها انجام شده است. شواهد تجربى ابتدا نشان مى دهد كه سهم عوامل توليد در بين كشورهاو در طول

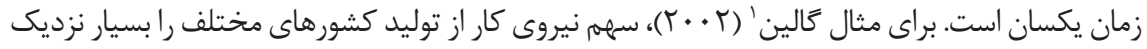

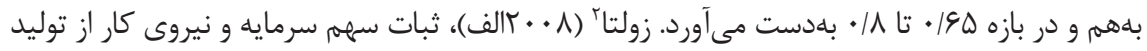
كشورها را تاييد مى كند. تفكيك هر يك از عوامل توليد و بررسى سهرم آنها نتايج بالا را زير سوال مىبرده.

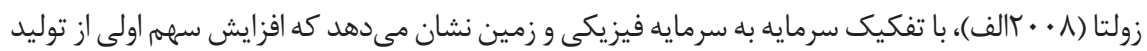
در بين كشورها به كاهش سهم دومى منجر مىشود. همجنين، افزايش سهرم سرمايه انسانى با كاهش

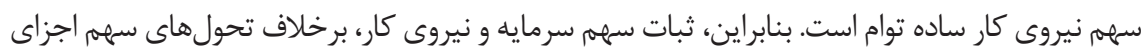

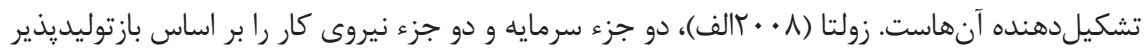

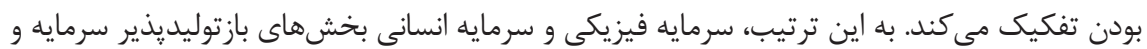
نيروى كار هستند، در حالى كه زمين و نيروى كار ساده بخش هاى بازتوليدنايذيرند.

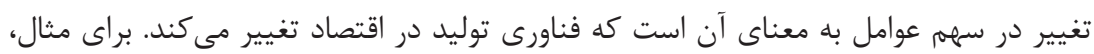
افزايش سهم سرمايه فيزيكى از توليد به معناى آن است كه فرايند توليد به سرمايه بيش از بـ بيش نيازمند است و در مقابل كمتر به زمين وابسته است. علت تغيير در سهمم عوامل توليد موضوع

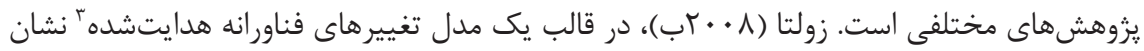

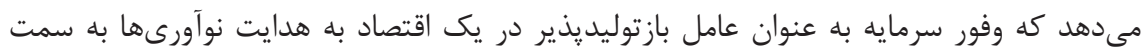

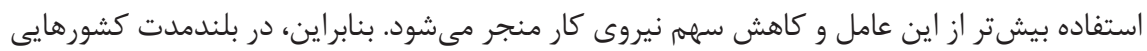
كه از وفور سرمايه بهرهمندند، به تابع توليدى كه فقط به سرمايه نيازمند است، يعنى تابع توليد AK

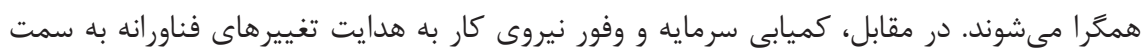

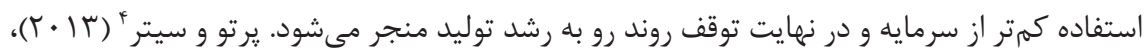

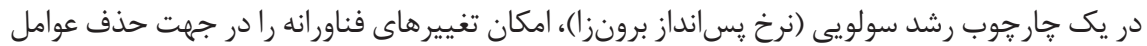
بازتوليدنايذير، مانند سرمايه طبيعى و نيروى كار ساده، و استفاده بيشتر از عوامل بازتوليديذير مانند

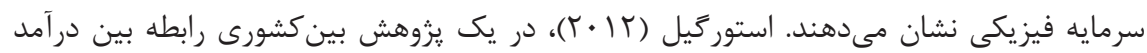

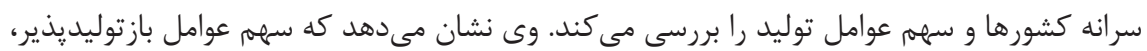

\section{Gollin}

2. Zuleta

3. Directed Technical Change

4. Peretto \& Seater 
يعنى نيروى كار ماهر و سرمايه فيزيكى، در كشورهايى با درآمد سرانه بالاتر بيشتر است. در مقابل،

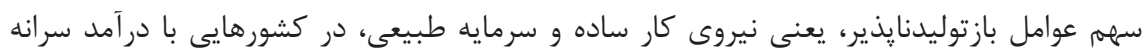

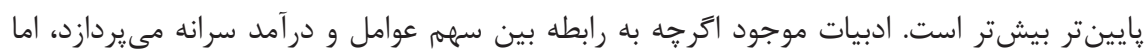

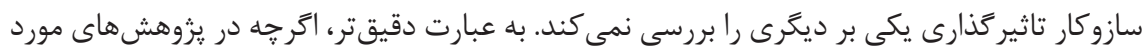
اشاره تفاوت در قيمتهاى نسبى عوامل توليد عامل تغيير سهم آنها از توليد معرفى مى شود، اما علت اين تغيير در قيمتها بررسى نمىشود (Peretto \& Seater, 2013; Zuleta, 2008b; Sturgill, 2012). يروهش حاضر با در نظركرفتن امكان تاثير برخوردارى از يا وابستخى به منابع طبيعى بر سهم عوامل

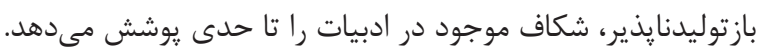
بخش ديخرى از ادبيات به شومى منابع مرتبط است. موضوع اين بخش از ادبيات تاثير برخوردارى

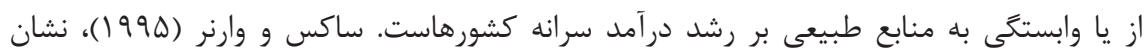
مى دهند كه كشورهاى ثروتمندتر از نظر منابع طبيعى نرخ رشد در آمد سرانه كمترى دارند. به دنبال آن، يزوهششهاى گستردهاى در مورد تاثير منابع طبيعى بر عملكرد اقتصادى كشورها انجام شده است.

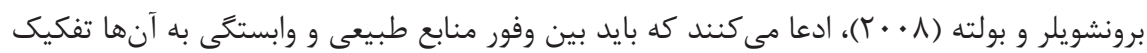
قائل شد. آنها نتيجه مى گيرند كه وفور منابع طبيعى اثر مثبتى بر رشد اقتصادى دارد؛ از طرف ديكر،

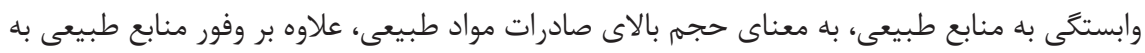

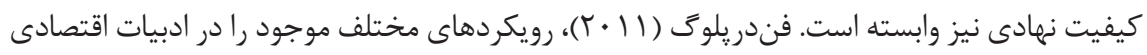

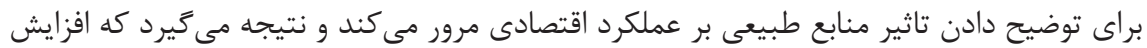
در آمدهاى حاصل از منابع طبيعى در كشورهايى با نوسانهاى بيشتر و نهادهاى بى كيفيتتر اثر منفى

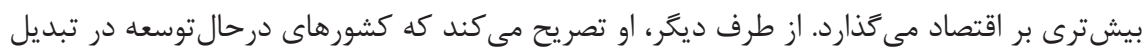

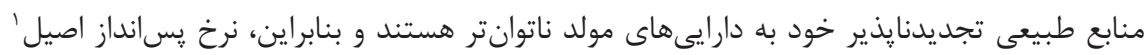
آنها منفى است و اين يعنى جشمهانداز رشد اقتصادى اين كشورها نايايدار است. اين يزوهش با بررسى اثر وابستكى به منابع طبيعى بر سهم عوامل توليد مى كوشد كه تاثير منابع را بر فناورى توليد اقتصاد آزمون كند. بر برون.

ا. پِسانداز اصيل يا Genuine Savings عبارت است از مجموع پِسانداز ناشى از در آمد توليدشده در يك مدت

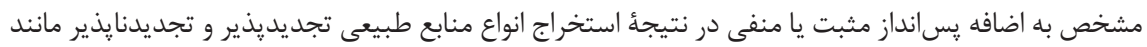

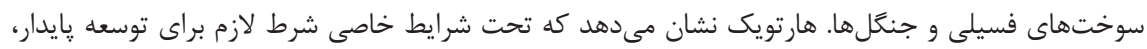
به معناى تضمين مصرف و در آمد ثابت تا ابد، داشتن نرخ يسانداز مهاز اصيل غيرمنفى است (Hartwick, 1977). 


\section{روششناسى يثوهش}

فرض كنيد محصول نهايى يك كشور توسط يك بنگاه در شرايط رقابت كامل و بر اساس يك تابع

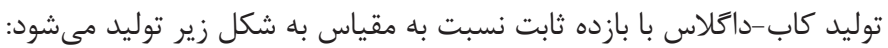
$Y_{i}=A_{i} K_{i}^{\alpha_{k}} N_{i}^{\alpha_{n}} H_{i}^{\alpha_{h}} L_{i}^{\alpha_{l}}$ كه در آن انديس i نشانكر كشور مورد نظر و متغيرهاى K، N، H، و LL بلترتيب سرمايه فيزيكى، سرمايه طبيعى، نيروى كار متخصص، و نيروى كار ساده مورد استفاده در توليد هستند. همجنين،

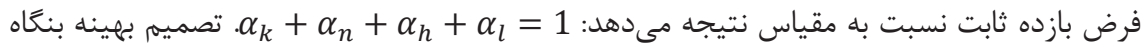
نمونه براى توليد محصول نهايى (بيشينهسازى سود)، به برابرى سهم هر يك از عوامل توليد با توان آن عامل در تابع توليد كاب_داگلاس منجر مىشود:

$\alpha_{x} \frac{Y_{i}}{X_{i}}=\frac{r_{x}}{P_{i}} \Rightarrow \alpha_{x}=\frac{r_{x} X_{i}}{P_{i} Y_{i}}$

در رابطه بالا، x نشانكر يكى از جهار عامل توليد، نهايى توليدشده در كشور i، و Y مقدار حقيقى توليد محصول نهايى آن كشور است. بنابراين، با استفاده از

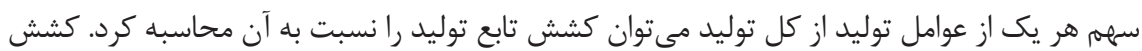
محاسبهشده همان توان عامل توليد مورد نظر در تابع توليد كابـداكلاس است. به همين دليل، سهرم يرداختى به هر عامل از كل ارزشافزوده هر كشور نمايانكر فرم تابع توليد آن كشور است. اتر در يك كشور

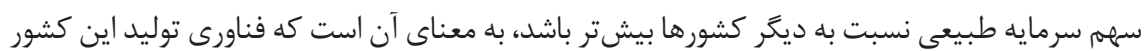
وابستكى بيشترى به سرمايه طبيعى دارد، يا a در اين كشور بيشتر است. يس ممكن است اين يرسش ״يش بيايد كه علت تفاوت در توانها، يا همان تفاوت در فرم تابع توليد يا فناورى توليد جيست. البته اين

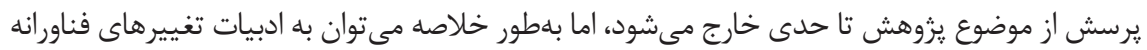

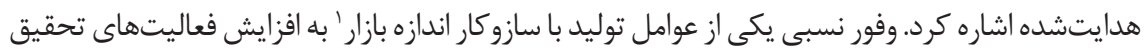

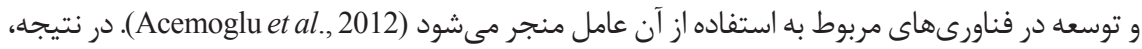

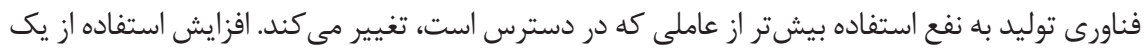

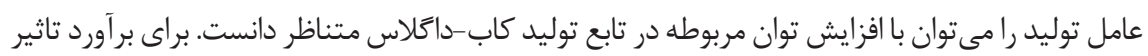

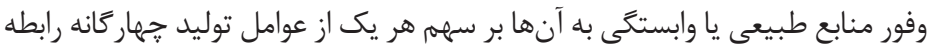


$\alpha=c_{0}+c_{1} r g d p l+c_{2} R+e$

به روشهاى مختلف برآورد مىشود. در رابطه (1)، $a_{0}$ سهم يكى از عوامل جهار Fانه توليد، rgdpl

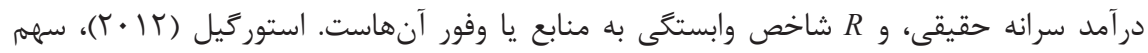
عوامل توليد جهاركانه را براى تعدادى از كشورها در سال ... . . محاسبه مى كند (ييوست ()). در اين

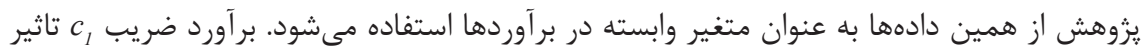

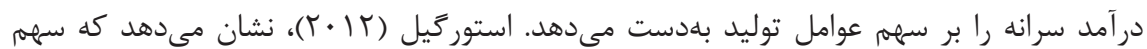
عوامل بازتوليدٍذير، يعنى سرمايه فيزيكى و نيروى كار متخصص، رابطه مثبتى با در آمد سرانه كشورها

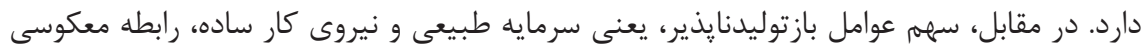

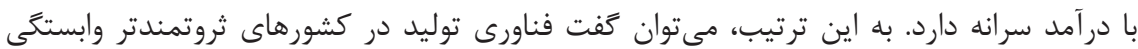
بيشترى به سرمايه فيزيكى و نيروى كار متخصص و وابستكى كمترى به سرمايه طبيعى و نيروى كار انسانى دارد. ضريب c رابطه بين وابستخى يا برخوردارى اقتصاد از منابع طبيعى را با سهمه عوامل توليد جهار كانه نمايند

يروهش حاضر به بررسى رابطه بين بهرهمندى از منابع طبيعى و سهم عوامل توليد در سطح كلان مجموعهاى از كشورها مىيردازد. ملاك انتخاب كشورها، تخمين سههم عوامل توليد جهار كانه استورگيل

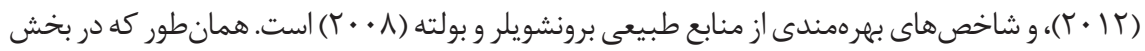

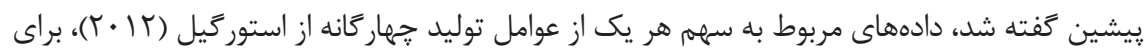

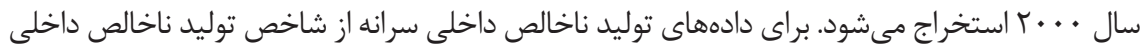

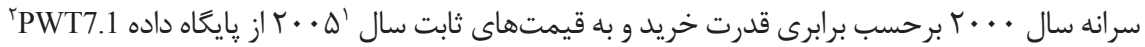
(Heston et al., 2012)

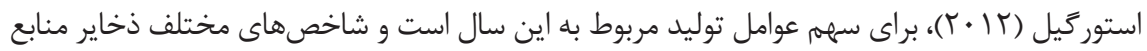
طبيعى كشورها نيز فقط براى برخى سالها موجود است كه سال . .. ب يكى از اين سالهاست. براى دادهاى مربوط به منابع از دو نوع شاخص استفاده مىشود. دسته يكم، شاخصهاى مربوط به وابستكى

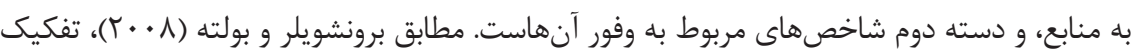


وابستكى اقتصاد به منابع طبيعى از حجم ذخاير موجود يا همان بهرهمندى از منابع طبيعى مىتواند

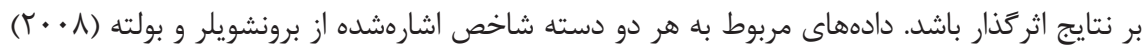

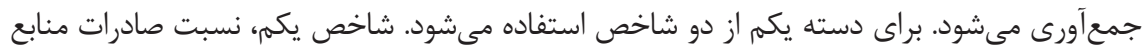
معدنى به توليد ناخالص داخلى (minxp) است كه به صورت متوسط نسبت صادرات سالانه منابع معدنى،

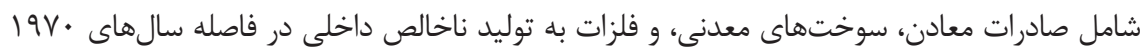
تا 9 19 19 محاسبه مى شود. شاخص دوم وابستكى به منابع طبيعى نسبت صادرات منابع طبيعى به توليد ناخالص داخلى (natxp) است كه به صورت متوسط نسبت صادرات سالانه مواد معدنى و مواد خام

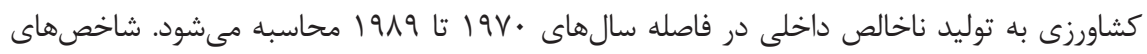

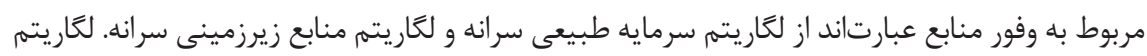

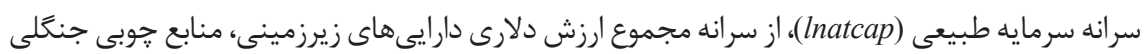

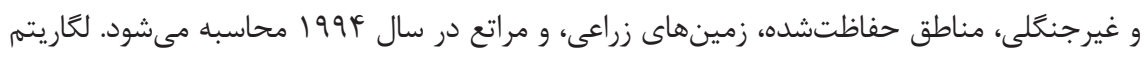

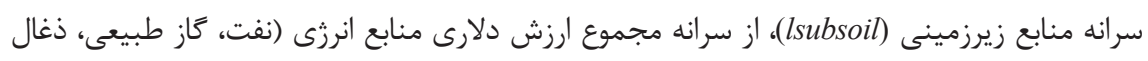

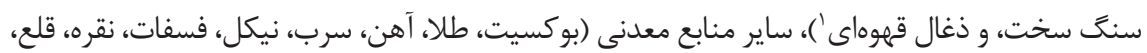

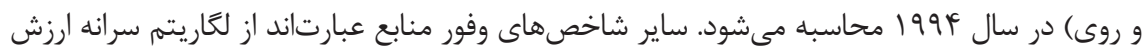

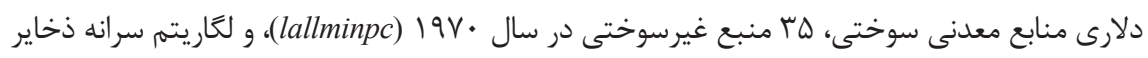

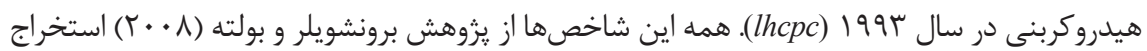

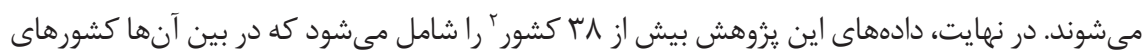
برخوردار از منابع طبيعى، كشورهاى توسعهيافته، و كشورهاى در حال توسعه حضور دارند.

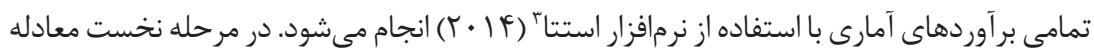

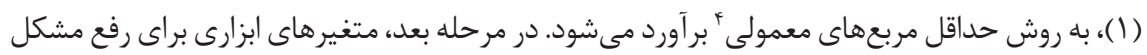

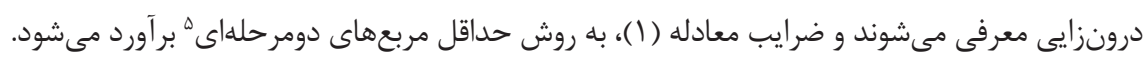

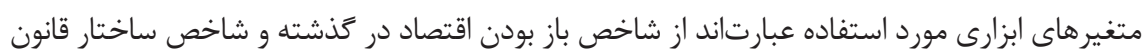

\section{Lignite}

ז. در مورد برخى از متغيرها تعداد مشاهدهها بيشتر است و در هر برآورد بسته به متغيرهاى مورد استفاده تعداد

3. STATA مشاهدهها تغيير مى كند.

4. Ordinary Least Squares (OLS)

5. Two-Stage Least Square (2SLS) 
اساسى. شاخص باز بودن اقتصاد در گذشته، يعنى دهdهاى • 194 و •199 ميلادى، از تقسيم مجموع صادرات و واردات بر توليد ناخالص داخلى محاسبه مىشود (open5060)، و همجٍنين، شاخص ساختار

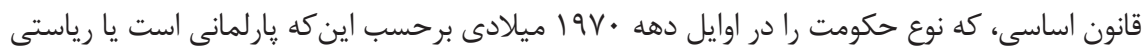

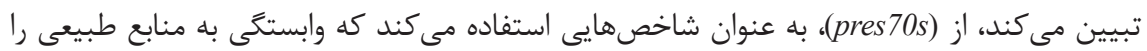
توضيح مى دهند، اما تا حد قابلقبولى بلندمدت و نسبت به وابستكى به منابع برونزا هستند. شاخص اخير در صورتى كه رييس دولت، رييس جمهورى باشد، يك و زمانى كه رييس دولت توسط يّارلمان

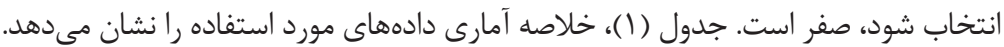

\section{جدول ا: خلاصه آمارى دادهها}

\begin{tabular}{|c|c|c|c|c|c|}
\hline حداكثر & حداقل & انحراف معيار & ميانگين & تعدادمشاهدهها & متغير \\
\hline$\cdot|f|$ & $\cdot 1 \cdot r$ & $\cdot 1 \cdot V$ &.$/ T t$ & is & $a_{k}$ \\
\hline$\cdot 100$ & .1 .9 &.$/ 14$ & $\cdot / r$ & fq & $a_{n}$ \\
\hline - & $\cdot 1 \cdot 1$ & $\cdot / 1$ & $\cdot / r \Delta$ & fe & $a_{h}$ \\
\hline.$/ 49$ & س & $\cdot 1 \cdot 9$ & س & is & $a_{l}$ \\
\hline . IVT &.$/ 1 \mathrm{~V}$ & • & $\cdot / \Delta V$ & FG & $a_{k}+a_{h}$ \\
\hline - /A૬ & • & .111 & $\cdot 109$ & is & $a_{h}+a_{l}$ \\
\hline$\cdot /$ FF & $\cdot 1 \cdot$ & $\cdot 1 \cdot 1$ & $\cdot 1 \cdot \Delta$ & ऍ & $\operatorname{minxp}$ \\
\hline V/AG & $\cdot 1 \cdot$ & $1 / 9$ & $\cdot 10$ & r^ & natxp \\
\hline אזr• & $\cdot 1 \cdot \cdots \wedge$ & $\cdot 1 \cdot 99$ & $\cdot 1 \cdot 1 \mathrm{~F}$ & fy & 'rgdpl \\
\hline $1 \cdot 1 \mathrm{Ar}$ & $\cdot / \cdots$ & $r / \wedge \Delta$ & r/Tr & rq & lsubsoil \\
\hline $1 \cdot 191$ & $\cdot 1 \cdot$ & $r / T V$ & $N / 11$ & $i \Delta$ & lnatcap \\
\hline $1 / \cdots$ & $-11 / 9$ & $r / q$. & $-\Delta / \wedge \Delta$ & (i) & lallminpc \\
\hline$N / r$ & $-|q| 9 \mid$ & $F / T$. & $1 / T V$ & f. & lhcpc \\
\hline t/AT & -.191 & $1 / \cdot r$ & . IVT & is & goveffect \\
\hline$r / I V$ & $-1 / T \Delta$ & $I / \cdot V$ & $\cdot / V \Delta$ & is & rule \\
\hline$\cdot|V|$ & $\cdot / \cdot$ f $^{-}$ & .119 & $\cdot|f|$ & is & latitude \\
\hline $1 / \cdots$ & $.1 \cdot$ & $\cdot|\Delta|$ & $\cdot|\Delta|$ & fl & pres $70 s$ \\
\hline N/DT &.$/ 10$ & $r / \cdot V$ & r & ५q & open 5060 \\
\hline
\end{tabular}




\section{نتايج تجر.بى}

جدول (Y)، نتايج تخمين معادله ( () را به روش حداقل مربعهاى معمولى نشان مى دهد. اعداد داخل

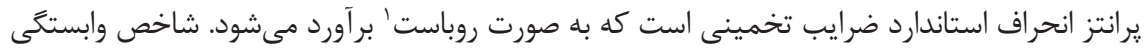
به منابع در اين تخمينها نسبت صادرات معدنى به توليد ناخالص داخلى است. همانطور كه در جدول (Y) ديده مىشود، در كشورهايى كه وابستكى به منابع معدنى بيشتر است، سهرم سرمايه طبيعى از توليد

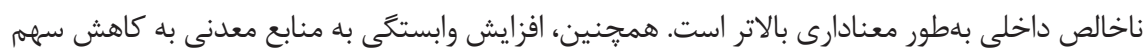
نيروى كار متخصص و ساده از توليد ناخالص داخلى منجر مىشود. به علاوه، سهم سرمايه فيزيكى در كشورهايى كه بيشتر به منابع معدنى وابستهاند، كمتر است. اثر وابستكى به منابع معدنى بر سهمم عوامل بازتوليديذير، يعنى مجموع سهم سرمايه فيزيكى و نيروى كار متخصص، و سهم نيروى كار هر دو منفى و

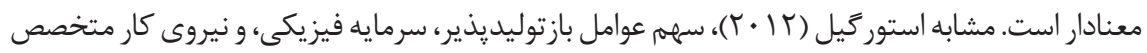
از توليد ناخالص داخلى در كشورهايى با درآمد سرانه بالاتر بيشتر است. به بيان ديخر، سهم عوامل بازتوليدنايذير، نيروى كار ساده و سرمايه طبيعى، در كشورهايى با درآمد سرانه يايينتر بيشتر است.

جدول זّ: تخمين حداقل مربعهاى معمولى براى وابستغى به منابع معدنى (minxp)، ^ץ مشاهده

\begin{tabular}{|c|c|c|c|c|c|c|}
\hline سيروى سرى & عوازمل قابل & سيروى كار & نيروى كار & سرمايه سبهم & سرمائه & \\
\hline 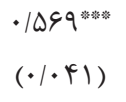 & 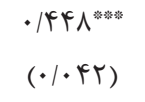 & $\begin{array}{l}\cdot / r \wedge \Delta^{* * * * * *} \\
(\cdot / \cdot r q)\end{array}$ & 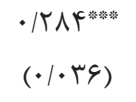 & 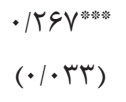 & 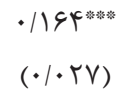 & عرض از مبدأ \\
\hline 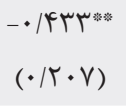 & 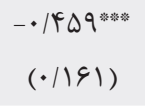 & $\begin{array}{l}-\cdot / I V r^{*} \\
(\cdot / \cdot V I)\end{array}$ & 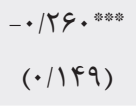 & 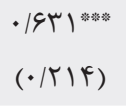 & $\begin{array}{l}-.1199^{\text {*** }} \\
(\cdot 1 \cdot 09)\end{array}$ & توليدناخالص صات معدنى به \\
\hline $\begin{array}{l}r / \mathcal{F} \cdot * \\
(I / V \Delta)\end{array}$ & $\begin{array}{l}9 / \Delta \Lambda^{* * w^{*}} \\
(1 / 91)\end{array}$ & 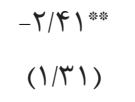 & 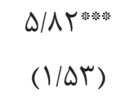 & $\begin{array}{l}-V / I V^{\text {*as }} \\
(1 / \mathcal{F} \wedge)\end{array}$ & $\begin{array}{l}r / V V^{* * *} \\
(1 / r q)\end{array}$ & سرانه توليدناخالص \\
\hline$\cdot 1 / 49$ & . &.$/ 1 \mathrm{~V}$ & $\cdot \mid k F$ & $\cdot 19$ & سאן. & Adjusted $\mathrm{R}^{2}$ \\
\hline $.1 \cdot 9$ & $\cdot 1 \cdot 1$ & $\cdot 1 \cdot \Delta$ & $\cdot / \cdot V$ & $\cdot 1 \cdot 1$ & $.1 \cdot 9$ & Root MSE \\
\hline
\end{tabular}

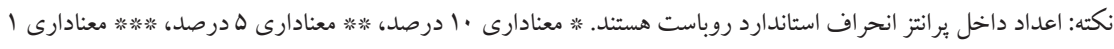
درصد را نشان مى دهد.

جدول (Y)، رابطه بين وابستكى به منابع طبيعى و سهم عوامل توليد را بررسى مى كند. به عبارت 1. Robust 
ديكر، در اين جدول نتايج تخمين معادله ( () ارائه داده مىشود، در صورتى كه از نسبت صادرات منابع

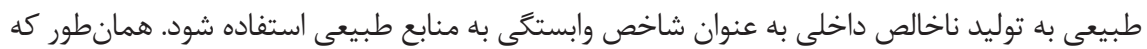

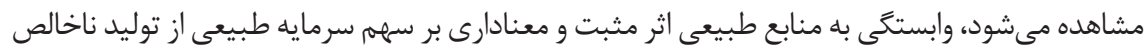

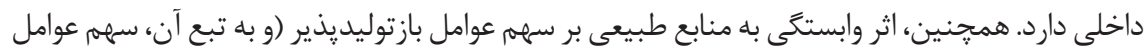

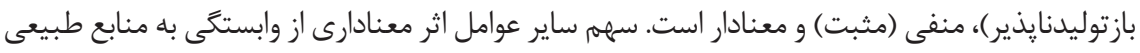
نمى يذيرند. جداول (r) و (Y)، تاثير شاخصهاى وابستكى به منابع را بر سهمم عوامل توليد نشان مى دهند.

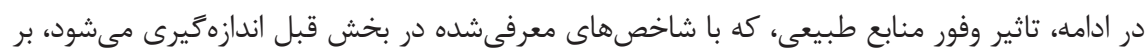

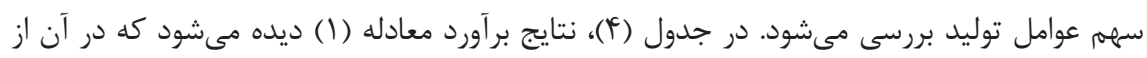
ميزان ذخاير زيرزمينى به عنوان شاخص وفور منابع استفاده مىشود. ضرايب تخمينى نشان مى مدهد كه

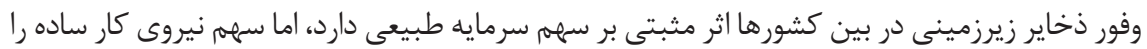
كاهش مى دهد و بر سهمم سرمايه فيزيكى و نيروى كار متخصص اثر معنادارى ندارد. به علاوه، وفور ذخاير

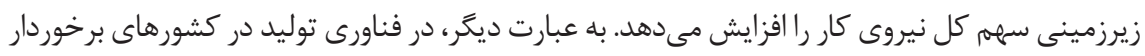
از ذخاير زيرزمينى، در مقايسه با كشورهاى ديكر، سرمايه طبيعى جانشين نيروى كار ساده مى شيود.

جدول بّ: تخمين حداقل مربعهاى معمولى براى وابستغى به منابع طبيعى (natxp)، مب مشاهده

\begin{tabular}{|c|c|c|c|c|c|c|}
\hline سيروى سرم & قابل باز تولهم & كار سيروى سهره & كار متخصص سيروى سهم & سرمايه & سيزيكى سهايه & \\
\hline 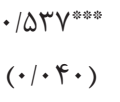 & 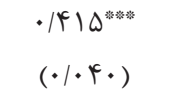 & 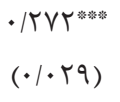 & 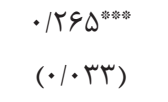 & 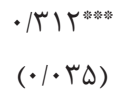 & 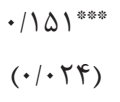 & عرض از مبدأ \\
\hline $\begin{array}{l}-\Lambda / \Lambda \Lambda \\
(\Lambda / \vee \Lambda)\end{array}$ & 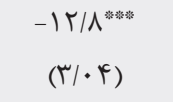 & $\begin{array}{l}-Y / A Y \\
(F / T Y)\end{array}$ & $\begin{array}{l}-\Delta / \mu \mathcal{F} \\
(\mathcal{F} / V \varphi)\end{array}$ & $\begin{array}{l}10 / 9^{\text {was }} \\
(9 / \cdot 1)\end{array}$ & $\begin{array}{l}-V / F F \\
(F / G \wedge)\end{array}$ & توليدناخالص داخلى ' طبيعى \\
\hline 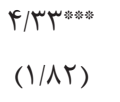 & $\begin{array}{l}1 \cdot / 9^{* * * *} \\
(1 / \mathrm{AV})\end{array}$ & $\begin{array}{l}-r / \cdot F \\
(1 / r /)\end{array}$ & $\begin{array}{l}9 / \Gamma \Lambda^{* * a n} \\
(1 / \Delta 1)\end{array}$ & $\begin{array}{c}-\Lambda / \Delta V^{* \omega *} \\
(1 / 91)\end{array}$ & 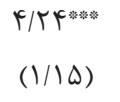 & سرانه توليد ناخالص \\
\hline .119 & $\cdot \mid \Delta \Lambda$ &.$/ 1 T$ & $\cdot / 4$. & $\cdot / \& V$ & • & Adjusted $\mathrm{R}^{2}$ \\
\hline .11. & .1 .9 & $\cdot 1 \cdot \Delta$ & $\cdot / \cdot V$ & .1 .9 & .1 .9 & Root MSE \\
\hline
\end{tabular}

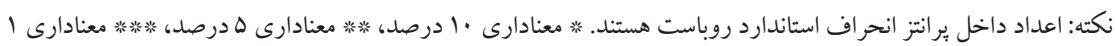
درصد را نشان مى مهند. 
جدول fا: تخمين حداقل مربعهاى معمولى براى وفور ذخاير زيرزمينى (Isubsoil)، rr مشاهده

\begin{tabular}{|c|c|c|c|c|c|c|}
\hline سيروى سهم & 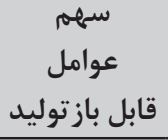 & كار ساده سهم & كار متخصصى سروم & سرمايه & سرمايه & \\
\hline 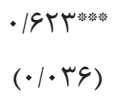 & $\begin{array}{l}\cdot / F F \cdot{ }^{*} w_{p} \\
(\cdot / \cdot V I)\end{array}$ & 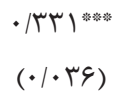 & 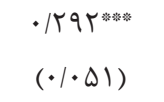 & 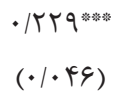 & 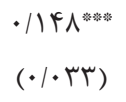 & عرض از مبدأ \\
\hline 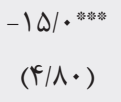 & $\begin{array}{l}-F / G F \\
(V / \Delta \Delta)\end{array}$ & $\begin{array}{l}-11 / 9^{* * * * *} \\
(1 / 99)\end{array}$ & $\begin{array}{l}-r / \mathcal{F T} \\
(\Delta / \Delta q)\end{array}$ & $\begin{array}{l}19 / \gamma^{* * * * a s} \\
(\Delta / \Lambda 1)\end{array}$ & $\begin{array}{l}-1 / T 4 \\
(T / 91)\end{array}$ & لَاريتم سرانه ذخاير \\
\hline 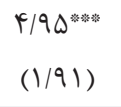 & 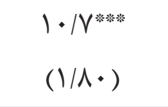 & $\begin{array}{l}-1 / T V \\
(9 / 10)\end{array}$ & 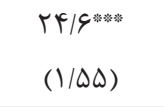 & 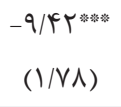 & 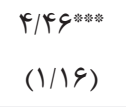 & سرانه توليد ناخالص \\
\hline$\cdot|\pi|$ & ש & .149 & & $\cdot \mid \Delta F$ & . & Adjusted R2 \\
\hline$\cdot 1 \cdot 1$ & $.1 \cdot 9$ & $\cdot 1 \cdot f$ & $\cdot 1 \cdot V$ & $\cdot 1 \cdot 1$ & $\cdot 1 \cdot 9$ & Root MSE \\
\hline
\end{tabular}

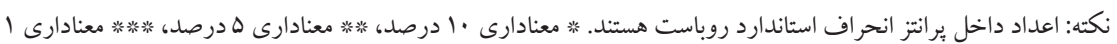
درصد را نشان مى دهد.

تخمينهاى جدولهاى (r و F) را مى توان براى وفور سرمايه طبيعى نيز تكرار كرد. جدول (ه)،

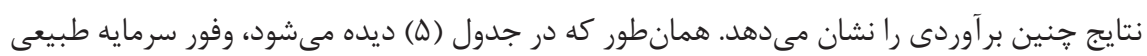
اثر معنادارى بر فناورى توليد در بين كشورها ندارد. 
جدول ه: تخمين حداقل مربعات معمولى براى وفور سرمايه طبيعى (Inatcap)، رب مشاهده

\begin{tabular}{|c|c|c|c|c|c|c|}
\hline سيروى سرم & قابل عوامل سـملم توليد & كار ساده سهرى & كارمتخصصى سيرم & سرمايهم سبيعى & سرمايه سيهم & \\
\hline 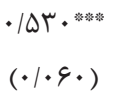 & 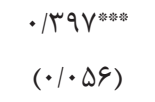 & 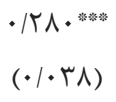 & 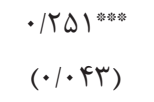 & 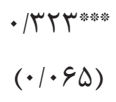 & 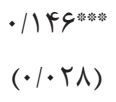 & عرض از مبدأ \\
\hline $\begin{array}{l}-1 / 91 \\
(0 / 94)\end{array}$ & $\begin{array}{l}-r / \cdot \Lambda \\
(\mathcal{L} / \mathcal{E})\end{array}$ & $\begin{array}{l}-Y / V V \\
(Y / \wedge \varphi)\end{array}$ & $\begin{array}{l}\cdot / \Lambda \Delta H \\
(r / Y \Delta)\end{array}$ & $\begin{array}{l}-\cdot / r \wedge \Delta \\
(\varepsilon / \& Y)\end{array}$ & $\begin{array}{l}T / T T \\
(T / \cdot 9)\end{array}$ & سراريتم سرانه \\
\hline 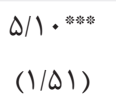 & $\begin{array}{l}1 \cdot / 1^{* w^{*}} \\
(1 / \vee \wedge)\end{array}$ & $\begin{array}{l}-1 / \Delta \varphi \\
(1 / \mid q)\end{array}$ & 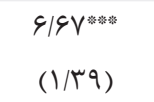 & $\begin{array}{c}-\Lambda / \Delta \varphi^{* * w^{*}} \\
(1 / \mathcal{F} \Delta)\end{array}$ & 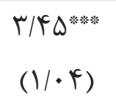 & سراخالص داخل توليد \\
\hline$\cdot|r|$ & $\cdot|\Delta|$ & $\cdot / V \Delta$ & $\cdot / k$. & $\cdot \mid k F$ & $\cdot / T T$ & Adjusted $\mathrm{R}^{2}$ \\
\hline$\cdot 1 \cdot 9$ & $.1 \cdot 9$ & .1 .9 & $\cdot 1 \cdot 1$ & .1 .9 & .1 .9 & Root MSE \\
\hline
\end{tabular}

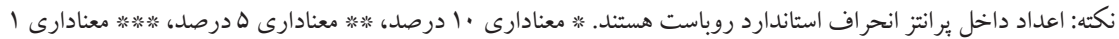
درصد را نشان مى مهد.

شاخص ديكرى كه نمايانگر وفور منابع طبيعى است، لمَاريتم سرانه ذخاير هيدروكربنى است.

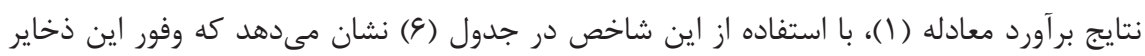
به افزايش سهم سرمايه طبيعى از توليد ناخالص داخلى و كاهش سهمم هر دو نوع نيروى كار منجر مىشود. به بيان ديكر، در كشورهايى كه ذخاير هيدروكربنى بيشترى دارند، در فناورى توليد سرمايه طبيعى را جايكزين انواع نيروى كار مى كنند. 


\begin{tabular}{|c|c|c|c|c|c|c|}
\hline سيروى كار & قابل بازتوليد & نيروى كار & كار متخصصى سيروى & سرمايه & سرماينه & \\
\hline $\begin{array}{l}\cdot / \Delta \cdot \Lambda^{* \omega * a} \\
(\cdot / \cdot r \Delta)\end{array}$ & 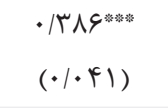 & $\begin{array}{l}\cdot / T V \Lambda^{* * a s} \\
(\cdot / \cdot T V)\end{array}$ & $\begin{array}{l}\cdot / r \cdot \cdot * \text { * } \\
(\cdot / \cdot T V)\end{array}$ & 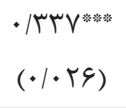 & $\begin{array}{l}\cdot / \mid \Delta \varphi^{* * *} \\
(\cdot / \cdot r r)\end{array}$ & عرض از مبدأ \\
\hline $\begin{array}{c}-1 \cdot / V^{w \omega *} \\
(\Gamma / / Q)\end{array}$ & $\begin{array}{l}-\Delta / 9 \varphi \\
(\Gamma / 9 V)\end{array}$ & $\begin{array}{l}-Q / F V^{* * *} \\
(T / \Psi \wedge)\end{array}$ & $\begin{array}{l}-\Delta / T \cdot * \\
(T / \Lambda F)\end{array}$ & $\begin{array}{l}11 / /^{* * a} \\
(r / \cdot F)\end{array}$ & $\begin{array}{l}-\cdot / F \Delta \Lambda \\
(T / \Delta T)\end{array}$ & لحاريتم سرانه سرمايه \\
\hline $\begin{array}{l}9 / 1 \cdot \cdots \\
(1 / 1 Q)\end{array}$ & $\begin{array}{l}\mid Y / \cdot * * * * \\
(1 / \wedge \varphi)\end{array}$ & $\begin{array}{l}-Y / \cdot r^{*} \\
(1 / / \Delta)\end{array}$ & $\begin{array}{l}N / / Y^{\text {*w*w }} \\
(1 / T T)\end{array}$ & $\begin{array}{l}-9 / 9 G^{*} \text { : } \\
(1 / T r)\end{array}$ & $\begin{array}{l}r / \Lambda \Delta^{* w} \\
(1 / / \Delta)\end{array}$ & سرانه توليد ناخالص \\
\hline . & $\cdot 190$ & $\cdot / T \Lambda$ & . 194 & $\cdot 19 V$ & $\cdot / r V$ & Adjusted $\mathrm{R}^{2}$ \\
\hline$\cdot / \cdot V$ & .1 .9 & $\cdot / \cdot \Delta$ & .1 .9 & $\cdot / \cdot V$ & .1 .9 & Root MSE \\
\hline
\end{tabular}

آخرين شاخص وفور منابع لمًاريتم سرانه ذخاير معدنى است. نتايج استفاده از اين شاخص در برآورد معادله ( ()، كه در جدول (V) درج مىشود، نشان مى مهد كه كشورهاى برخوردار از ذخاير معدنى غنىتر در توليد ناخالص داخلى خود كمتر از سرمايه فيزيكى و نيروى كار ساده استفاده مى كنند و در عوض اين دو را در فرايند توليد با سرمايه طبيعى جايكزين ميى كنند. 
جدول ץ: تخمين حداقل مربع هاى معمولى براى وفور ذخاير معدنى (lallminpc)، ^ץ مشاهده

\begin{tabular}{|c|c|c|c|c|c|}
\hline سهمم & سهم & سهم & سهم & سهم & سهم \\
\hline نيروى & عوامل & نيروى & نيروى & سر مايه & سرمايه \\
\hline كار & قابل بازتوليد & كار ساده & كار متخصص & طبيعى & فيزيكى \\
\hline$\cdot / \uparrow \Delta Q^{*}$ & • & 的 & $\cdot / T T G^{*}$ & 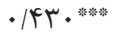 & $\cdot / 111^{* \text { wow }}$ \\
\hline
\end{tabular}

عرض از مبدأ

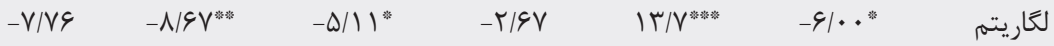

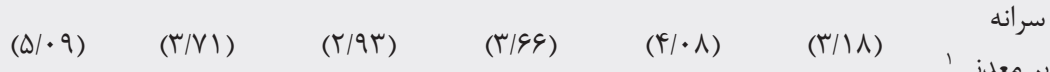

ذخاير معدنى

$\begin{array}{llllll}(1 / V Y) & (1 / V \varphi) & (1 / \cdot V) & (1 / F \Lambda) & (1 / \Delta F) & (1 / \cdot 1)\end{array}$

ناخالص داخلى

\begin{tabular}{|c|c|c|c|c|c|c|}
\hline r & $\cdot 109$ &.$/ 1 \mathrm{~V}$ & T & $\cdot / \Delta \Delta$ & $\cdot|r|$ & Adjusted $\mathrm{R}^{2}$ \\
\hline
\end{tabular}

\begin{tabular}{|c|c|c|c|c|c|c|}
\hline$\cdot / 1$ & $.1 \cdot 9$ & $\cdot / \cdot \Delta$ & $\cdot 1 \cdot 1$ & $\cdot / \cdot \Lambda$ & $.1 \cdot 9$ & Root MSE \\
\hline
\end{tabular}

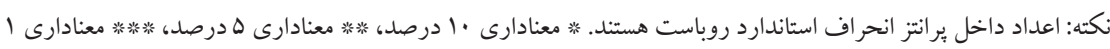
درصد را نشان مىدهن. 
نتايج بالا نشان مىدهد كه رابطه مثبتى بين وابستكى يا وفور منابع طبيعى و معدنى، و سهمم سرمايه طبيعى از توليد كشورها ديده مىشود. همجنين، تاثير وفور يا وابستكى به منابع تجديدنايذير

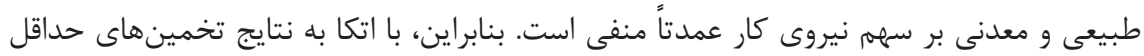

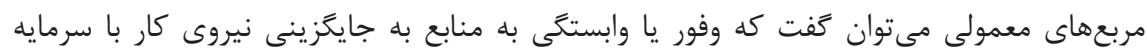
طبيعى در فناورى توليد منجر مىشود. به عبارت ديكر، در كشورهايى كه ذخاير طبيعى فراوانى در اختيار دارند يا وابستكى زيادى به اينگونه منابع دارند، فناورى توليد در سطح كلان وابستكى مئى

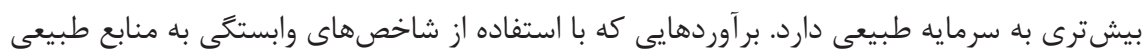

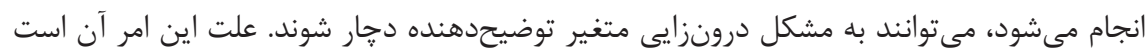

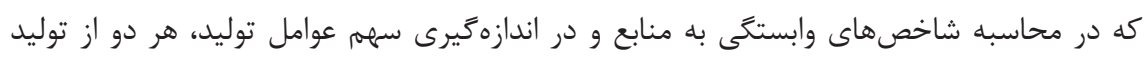

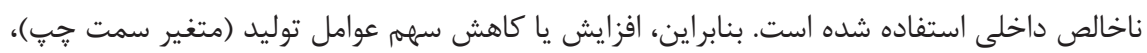

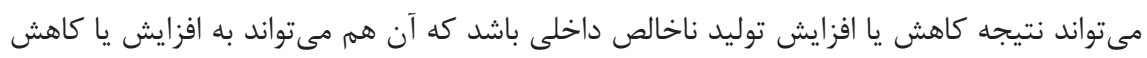

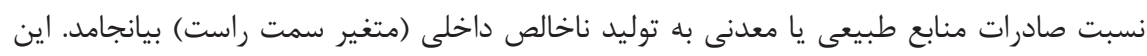

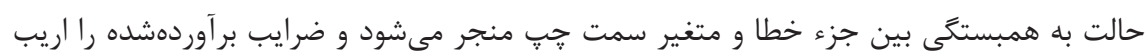
و بى استفاده مى كند.

براى رفع اين مشكل از متغير ابزارى استفاده مىشود. براى ابزار كردن وابستخى به منابع طبيعى،

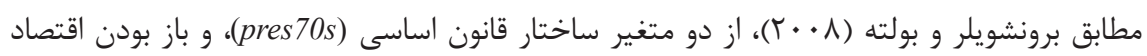

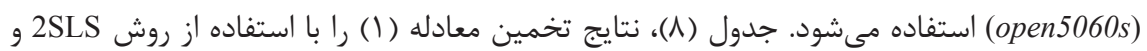
استفاده از نسبت صادرات معدنى به توليد ناخالص داخلى نشان ميىدهد. در اين جدول، فقط نتايج

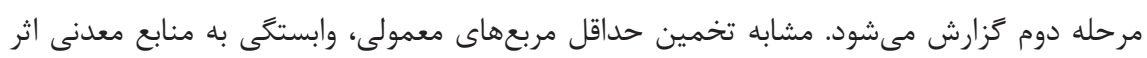

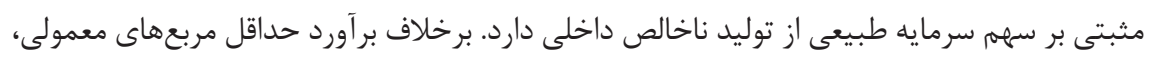

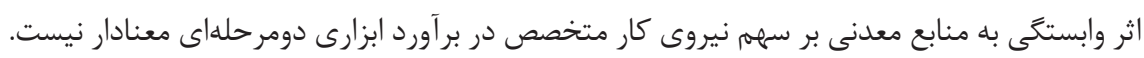

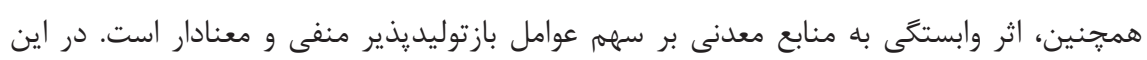

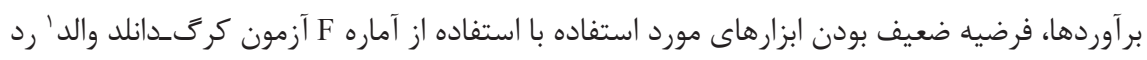

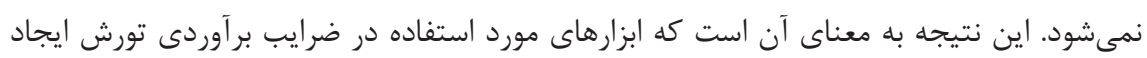

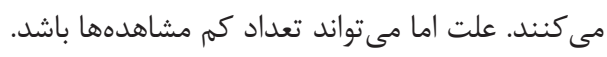


جدول م: تخمين 2SLS براى نسبت صادرات معدنى به توليد ناخالص داخلى، צr مشاهده

\begin{tabular}{|c|c|c|c|c|c|}
\hline سهم & سهم & سهمم & سهمم & سهمم & سمهم \\
\hline نيروى & عوامل & نيروى & نيروى & سرمايه & سرمايه \\
\hline كار & قابل باز توليد & كار ساده & كار متخصص & طبيعى & فيزيكى \\
\hline$\cdot \mid \Delta V V^{* * * * a}$ & $\cdot / \mathcal{f} \Delta \boldsymbol{S}^{*}$ & $\cdot / T \wedge \gamma^{*}$ & 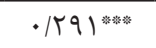 & 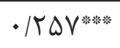 & $.1199^{*}$ \\
\hline$(\cdot / \cdot \Delta 1)$ & $(\cdot / \cdot F r)$ & $(\cdot / \cdot|r|)$ & $(\cdot / \cdot r q)$ & $(\cdot / \cdot f \cdot)$ & $(\cdot / \cdot r \cdot)$ \\
\hline
\end{tabular}

$$
\text { صادرات معدنى به }
$$

توليد ناخالص داخلى (

سرانه توليد ناخالص
$(1 / \mathrm{A})$
$(1 / \wedge \omega)$
$(1 / \mu 1)$
$(1 / \Delta \Delta)$
$(1 / 09)$
$(1 / Y \Lambda)$
داخلى

$\cdot 1 \cdot 9$

$\cdot / \cdot \Lambda$

$\cdot 1 \cdot \Delta$

$\cdot / \cdot \vee$

$\cdot 1 \cdot 1$

$\cdot 1 \cdot 9$

Root MSE

\begin{tabular}{|c|c|c|c|c|c|}
\hline $9 / 14$ & G/IF & G/IF & $9 / 14$ & $9 / 1 f$ & $9 / 1 F$ \\
\hline
\end{tabular}

\begin{tabular}{|c|c|c|c|c|c|c|}
\hline \multicolumn{7}{|c|}{ مقادير بحرانى فرض ضعيف بودن متغير ابزارى } \\
\hline 19/94 & 19/9r & $19 / 94$ & $19 / 94$ & $19 / 94$ & $19 / 91$ & بيشينه · ا درصد \\
\hline $11 / 09$ & $11 / 09$ & $11 / 09$ & $11 / 09$ & $11 / 09$ & $11 / 09$ & بيشينه ها درصد \\
\hline N/VQ & $\Lambda / V \Delta$ & $\Lambda / \vee \Delta$ & $\Lambda / \vee \Delta$ & $\Lambda / \vee \Delta$ & $\Lambda / \vee \Delta$ & بيشينه ·· درصد \\
\hline$V / T \Delta$ & $V / T \Delta$ & $V / T \Delta$ & $V / T \Delta$ & $V / T \Delta$ & $V / T \Delta$ & بيشينه لا درصد \\
\hline
\end{tabular}

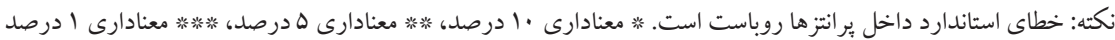
را نشان مىدهد. 
اثر وابستكى به صادرات منابع طبيعى نيز مشابه با برآورد بالا و با استفاده از ساختار قانون اساسى

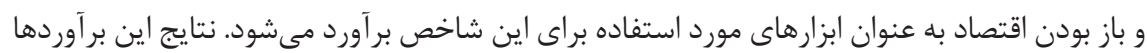

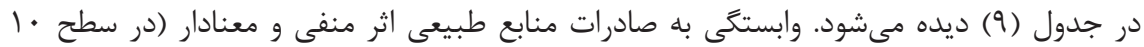
درصد)، بر سهم سرمايه فيزيكى از توليد ناخالص داخلى دارد. به علاوه، اثر وابستكى به منابع طبيعى لـى

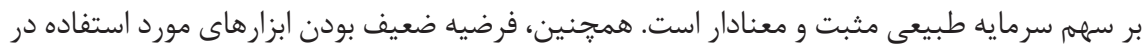

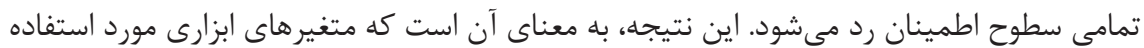
در تخمين ضرايب، تورش ايجاد نمى كنند.

جدول q: تخمين 2SLS راى نسبت صادرات طبيعى به توليد ناخالص داخلى، צب مشاهده

\begin{tabular}{|c|c|c|c|c|c|c|}
\hline سيروى كار & عوامل قابل & كار ساده سهم & نيروى كار & سرمايهم سبيعى سبيه & سرمايهم & \\
\hline 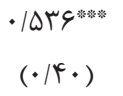 & $\begin{array}{l}\cdot|f| \cdot{ }^{* * * *} \\
(\cdot / \cdot \mid r q)\end{array}$ & 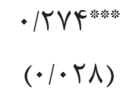 & 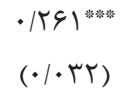 & 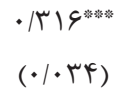 & 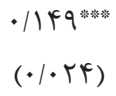 & عرض از مبدأ \\
\hline $\begin{array}{l}-\Delta / 9 r \\
(q / r r)\end{array}$ & $\begin{array}{l}-\mid \Psi / V^{* * * *} \\
(\mathcal{F} / \mid \Delta)\end{array}$ & $\begin{array}{l}-1 / \mathcal{F V} \\
(\mathcal{F} / \mathcal{F})\end{array}$ & $\begin{array}{l}-F / F G \\
(f / q F)\end{array}$ & 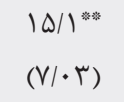 & $\begin{array}{l}-q / Y)^{*} \\
(\Delta / r r)\end{array}$ & صادرات طبيعى به \\
\hline $\begin{array}{l}F / \Gamma \Delta^{* * 5} \\
(I / \vee \Lambda)\end{array}$ & 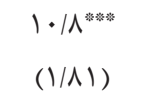 & $\begin{array}{l}-r / 1 \Lambda^{*} \\
(1 / r \Lambda)\end{array}$ & 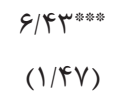 & $\begin{array}{l}-\Lambda / \Delta 9^{* * * * *} \\
(1 / \Delta \varphi)\end{array}$ & 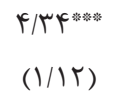 & سرانه توليد ناخالص \\
\hline $.1 \cdot 9$ & $\cdot 1 \cdot 1$ & $\cdot 1 \cdot \Delta$ & $\cdot 1 \cdot \mathrm{V}$ & $.1 \cdot 9$ & $.1 \cdot 4$ & Root MSE \\
\hline$r F \cdot / V$ & $r F \cdot / V T$ & $r F \cdot / r r$ & Tr./VT & $r F \cdot / V T$ & $r F \cdot / r r$ & $\begin{array}{c}\text { Weak identification } \\
\text { test (Cragg-Donald } \\
\text { Wald F statistic) }\end{array}$ \\
\hline \multicolumn{7}{|c|}{ مقادير بحرانى فرض ضعيف بودن متغير ابزارى } \\
\hline 19/91 & 19/9 & 19/9r & 19/94 & 19/9r & 19/91 & بيشينه · ا درصد \\
\hline $11 / 09$ & $11 / 09$ & $11 / 09$ & $11 / 09$ & $11 / 09$ & $11 / 09$ & بيشينه ها درصد \\
\hline$\Lambda / \vee \Delta$ & $\Lambda / \vee \Delta$ & $\Lambda / \vee \Delta$ & $\Lambda / \vee \Delta$ & N/VD & $\Lambda / \vee \Delta$ & بيشينه · † درصد \\
\hline$V / T \Delta$ & $V / T \Delta$ & $V / T \Delta$ & $V / T \Delta$ & $V / T \Delta$ & $\mathrm{V} / \mathrm{T \Delta}$ & بيشينه ه د درصد \\
\hline
\end{tabular}

نكته: خطاى استاندارد داخل برانتزها روباست است. را نشان مى دهد. 


\section{بحث و نتيجه Fيرى}

اين يزوهش به دنبال يافتن رابطه بين بهرهمندى كشورها از منابع طبيعى و فناورى توليد در

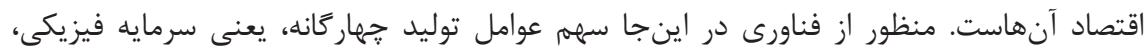
سرمايه طبيعى، نيروى كار ساده، و نيروى كار ماهر است. نتايج نشان مىدهد كه در كشورهايى كه

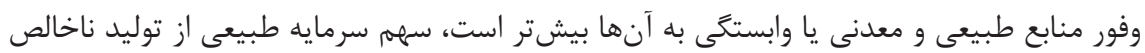

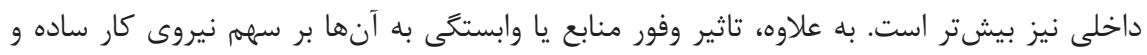

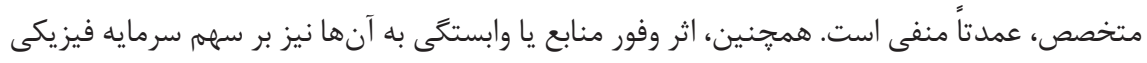
منفى است، اما كاه اين اثر معنادار نيست. با وجود اين، به نظر مى رسد كه شواهد تجربى، شومى منابع

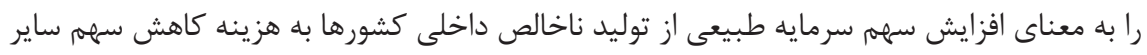
عوامل، بلويزه نيروى كار، تاييد مى كند.

يزوهش حاضر نخستين يزوهشى است كه تاثير منابع طبيعى را بر سهم عوامل توليد اقتصاد كلان به صورت تجربى مى آزمايد. البته يرسش از سازوكار اثرگذارى بهرهمندى از منابع طبيعى بر سهمه يهم

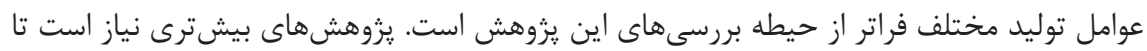
سازوكارى را بسازند كه در آن سهم عوامل توليد از وابستخى يا وفور منابع تجديدنايذير متاثر شود. به علاوه، يروهش در مورد سياستهاى موثر براى افزايش سهمم سرمايه فيزيكى و نيروى كار مىتواند براى سياستخذارى راهَشا باشد. 


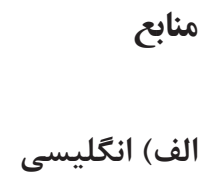

Acemoglu, D., Aghion, P., Bursztyn, L., \& Hemous, D. (2012). The Environment and Directed Technical Change. American Economic Review, 102(1), 131-166.

Alexeev, M., \& Conrad, R. (2009). The Elusive Curse of Oil. The Review of Economics and Statistics, 91(3), 586-598.

Brunnschweiler, C. N., \& Bulte, E. H. (2008). The Resource Curse Revisited and Revised: A Tale of Paradoxes and Red Herrings. Journal of Environmental Economics and Management, 55(3), 248-264.

Gollin, D. (2002). Getting Income Shares Right. Journal of Political Economy, 110(2), 458-474.

Hartwick, J. M. (1977). Intergenerational Equity and the Investing of Rents from Exhaustible Resources. The American Economic Review, 67(5), 972-974.

Heston, A., Summers, R., \& Aten, B. (2012). Penn World Table Version 7.1. Center for International Comparisons of Production, Income and Prices at the University of Pennsylvania, Philadelphia.

Jones, C. I. (2016). The Facts of Economic Growth. Handbook of Macroeconomics (Vol. 2, 3-69): Elsevier.

Kaldor, N. (1957). A Model of Economic Growth. The Economic Journal, 67(268), 591624.

Karabarbounis, L., \& Neiman, B. (2014). The Global Decline of the Labor Share. The Quarterly Journal of Economics, 129(1), 61-103.

Peretto, P. F., \& Seater, J. J. (2013). Factor-Eliminating Technical Change. Journal of Monetary Economics, 60(4), 459-473.

Sachs, J. D., \& Warner, A. M. (1995). Natural Resource Abundance and Economic Growth. NBER Working Paper, 5398.

Sturgill, B. (2012). The Relationship between Factor Shares and Economic Development. Journal of Macroeconomics, 34(4), 1044-1062.

Van der Ploeg, F. (2011). Natural Resources: Curse or Blessing? Journal of Economic Literature, 49(2), 366-420.

Zuleta, H. (2008a). An Empirical Note on Factor Shares. Journal of International Trade and Economic Development, 17(3), 379-390.

Zuleta, H. (2008b). Factor Saving Innovations and Factor Income Shares. Review of Economic Dynamics, 11(4), 836-851. 
بيوست: سهم عوامل توليد كشورهاى مختلف

جدول اب: سهم عوامل توليد كشورهاى مختلف

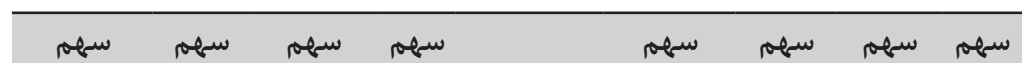

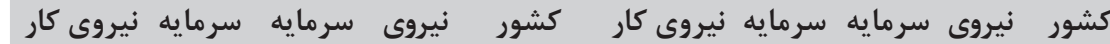

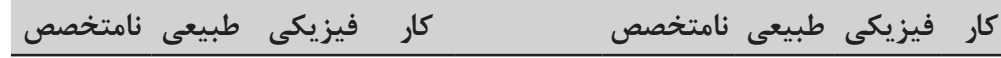

\begin{tabular}{|c|c|c|c|c|c|c|c|c|c|}
\hline$\cdot|\pi|$ & $\cdot 1 \cdot 1$ & $\cdot / \pi$ & $\cdot|4|$ & زاين & $\cdot / r$ & $\cdot / 1 \mathrm{~V}$ & $\cdot / T T$ & $\cdot / 4 T$ & استراليا \\
\hline ./TS & .1 .9 & $\cdot / I V$ &.$|\Delta|$ & جمهورى كره & $\cdot / K F$ & $\cdot / 1$ & $\cdot / \pi q$ & $\cdot|4|$ & اتريش \\
\hline .119 & $\cdot / r$ & $\cdot / 14$ & $\cdot / \pi \Delta$ & لتونى & . & $\cdot 1 \cdot 1$ & $\cdot / r \Lambda$ & $\cdot|4|$ & بلزيك \\
\hline .119 & $\cdot / K F$ & $\cdot \pi \cdot$ & $\cdot / \pi \varphi$ & مكزيك & . /Ir & $\cdot / r \Lambda$ & $\cdot|f|$ & .119 & بوتسوانا \\
\hline$\cdot / r$ & $\cdot / r \Delta$ & $\cdot / T r$ & $\cdot / K F$ & مولداوى & $\cdot / K F$ & $\cdot / T F$ & $\cdot / T r$ & $\cdot / r \cdot$ & برزيل \\
\hline . Tr & $\cdot / \pi \Delta$ & $\cdot / 10$ & $\cdot / \cdot \Lambda$ & موزامبيك & $\cdot / 1 \mathrm{~V}$ & $\cdot / r \Lambda$ & $\cdot / r V$ & $\cdot / r \Lambda$ & بلغارستان \\
\hline . &.$/ 1 r$ &.$/ 1 V$ & $\cdot / 4 q$ & ناميبيا & $\cdot|r|$ & $\cdot \pi$ & .119 & $\cdot|4|$ & كانادا \\
\hline$\cdot / r T$ & $\cdot / 1$ & $\cdot / T V$ & $\cdot|f|$ & هلند & $\cdot / r$ & $\cdot / r q$ & .119 & ש & شيلى \\
\hline$\cdot / r$ & $\cdot / r \Delta$ & $\cdot 110$ & $\cdot / f \cdot$ & زلاندنو & $\cdot / T r$ & $\cdot|r|$ & $\cdot / 19$ & $\cdot|r|$ & كلمبيا \\
\hline .149 & $\cdot / \mu F$ & $\cdot / \cdot f$ & . & نيجريه & $\cdot / r \Lambda$ & $\cdot / 1 V$ & $\cdot 111$ & $\cdot / F^{\prime}$ & كاستاريكا \\
\hline .119 & $\cdot|\pi|$ & $\cdot / 49$ & $\cdot / \pi \Delta$ & نروز & . & $\cdot / 4$ & $\cdot / 1$ & .119 & ساحل عاج \\
\hline$\cdot 111$ & $\cdot / T^{F}$ & $\cdot / 49$ & $\cdot / 49$ & ياناما & $\cdot / r \Delta$ & $\cdot / 1$ & $\cdot \pi r$ & . AT & دانمارى \\
\hline$\cdot / T \Lambda$ & .1 .9 & $\cdot / r \Delta$ & $\cdot / \mu$ & يرتغال & $\cdot / K T$ & $\cdot|r|$ & $\cdot / \pi \Delta$ & . & مصر \\
\hline ש & $\cdot / \cdot V$ & $\cdot / \cdot 1$ & . & رومانى & .119 & $\cdot / 1 \mathrm{~V}$ & $\cdot / \pi s$ & $\cdot / \mu \Lambda$ & اتيويى \\
\hline .119 & $\cdot / r \Lambda$ & $\cdot / 11$ & $\cdot / \pi \Delta$ & روسيه & $\cdot / K r$ &.$/ 14$ & $\cdot / \mu$ & $\cdot / \mu F$ & فنلاند \\
\hline$\cdot / r \Delta$ & $\cdot / 1$ & $\cdot / r \Delta$ & $\cdot|4|$ & اسيانيا & $\cdot / F^{F}$ & $\cdot / 1$ & $\cdot / \pi q$ & $\cdot|4|$ & فرانسه \\
\hline תואו & .1 .9 & $\cdot / T r$ & $\cdot 149$ & سوئد & $\cdot / K F$ & $\cdot 1 \cdot 1$ & $\cdot / r \Delta$ & r & آلمان \\
\hline$\cdot 1 / 4$ & $\cdot 1 \cdot 1$ & $\cdot / r \Delta$ & $\cdot|f|$ & سوييس & $\cdot|r|$ &.$/ 1 \mathrm{~F}$ & . & $\cdot / \mu F$ & يونان \\
\hline$\cdot|r|$ & ع & $\cdot / 1 T$ & $\cdot / T 1$ & توباگو & $\cdot / T V$ & $\cdot / T F$ & $\cdot / I V$ & • & هندوراس \\
\hline$\cdot \pi \cdot$ & $\cdot / r$ & .119 & •/KI & تونس & $\cdot|r|$ & .119 & $\cdot / \pi \Delta$ & • & مجارستان \\
\hline$\cdot / \pi 9$ & .1 .9 & 每 & . MT & انعَلستان & .119 & $\cdot 1 \Delta \Delta$ & $\cdot 11$ & .119 & ايران \\
\hline$\cdot / r T$ & .1 .9 & .119 & $\cdot 10$ & آمريكا & $\cdot / r \Delta$ & $\cdot / \cdot V$ & $\cdot|r|$ & $\cdot / 4 V$ & اسراييل \\
\hline$\cdot / r$ & . A & .119 & $\cdot / K T$ & ونزوئلا & $\cdot|r|$ &.$/ 1 T$ & $\cdot / \mu F$ & זr/. & ايتاليا \\
\hline
\end{tabular}


